\title{
Self-Regulation to Maintain Moderate Self-Views: Prior Self-Regulation Increases Biases Related to Self-Esteem
}

\author{
Matthew T. Gailliot ${ }^{*}$, Anne L. Zell ${ }^{2}$ \\ ${ }^{1}$ Center for Human Science, Chapel Hill, USA \\ ${ }^{2}$ Augustana College, Rock Island, USA \\ Email: ${ }^{\text {mgailliot@gmail.com }}$
}

Received 7 September 2014; revised 20 October 2014; accepted 23 November 2014

Copyright (C) 2014 by authors and OALib.

This work is licensed under the Creative Commons Attribution International License (CC BY).

http://creativecommons.org/licenses/by/4.0/

(c) (†) Open Access

\begin{abstract}
High self-esteem is associated with biases in which the person overestimates their positivity, whereas low self-esteem is associated with underestimations of one's positivity. The current study examined whether these biases emerge more strongly when self-regulation is impaired. Participants first completed a task that either did or did not require self-regulation. They later interacted with another participant and indicated the extent to which they viewed themselves as having behaved positively during the interaction and to which the other participant viewed them positively. Higher self-esteem predicted a greater bias in overestimating the extent to which the other person viewed one positively, but this relationship was the strongest among participants who had completed the self-regulatory task. Past work has found that self-regulating impairs selfregulation later on. These findings therefore suggest that self-regulation is a mechanism through which personal biases are avoided and moderate views are maintained.
\end{abstract}

\section{Keywords}

Self-Esteem, Self-Views, Self-Control, Self-Regulation, Ego Depletion

Subject Areas: Psychology, Sociology

\section{Introduction}

Self-esteem is associated with a host of interpersonal biases that may not be reflected in objective reality (e.g., having better social skills) [1] [2]. The current work examined the extent to which biases related to self-esteem are moderated by self-regulation (or self-control). In particular, we examined whether impaired self-regulation would increase biases in self-esteem related to being viewed positively by others.

${ }^{*}$ Corresponding author.

How to cite this paper: Gailliot, M.T. and Zell, A.L. (2014) Self-Regulation to Maintain Moderate Self-Views: Prior Self-Regulation Increases Biases Related to Self-Esteem. Open Access Library Journal, 1: e1018.

http://dx.doi.org/10.4236/oalib.1101018 
High self-esteem is associated with viewing oneself favorably across many domains, yet objective evidence indicates that these favorable self-views do not match reality. For instance, people with high self-esteem tend to view themselves as more physically attractive than people with low self-esteem [3]. Others' ratings of physical attractiveness, however, show that people with high self-esteem are equally attractive as those with low self-esteem [4] [5]. Similarly, high self-esteem is associated with a bias to view oneself as being thinner than objective evidence indicates [6]. People with high self-esteem also tend to think of themselves as being smarter than people with low self-esteem, yet objective intelligence tests show no differences based on self-esteem [5].

The current work examined biases in being perceived positively by others. People with high self-esteem believe they are more likeable or popular than people with low self-esteem [7]-[9], but their beliefs are not confirmed by objective measures [10] [11]. One study, for instance, found that popularity ratings of students by their teachers showed no relationship to self-esteem [12]. In studies in which participants interacted with one another, people with high self-esteem indicated that they were more liked or viewed more positively by others than did people with low self-esteem, yet likeability and positivity ratings showed no differences based on selfesteem [13] [14].

The current work examined whether biases in positivity are influenced by self-regulation.

Self-regulation is the capacity to control one's thoughts, emotions, and behaviors. One common belief is that people should maintain moderate views [15] and avoid viewing themselves either as largely superior or inferior to others. We reasoned that biased views emerge from time to time, but that self-regulatory processes operate to enable people to view themselves in more realistic or moderate terms. Biased views regarding the self should become stronger if self-regulation is impaired.

Ample work demonstrates that using self-regulation impairs self-regulation afterwards [16]-[19], likely because self-regulating can deplete glucose in the bloodstream needed for later self-regulation [20]-[22]. To the extent that personal biases are moderated by self-regulation, they should be influenced by prior self-regulatory acts. Indeed, some work has found that self-regulating caused later increases in personal biases, including narcissistic views [15] and the self-serving bias (i.e., taking credit for good outcomes and avoiding blame for bad outcomes) [23]. In the current work, we hypothesized that biases in perceived self-positivity would be stronger among people with high self-esteem and weaker among people with low self-esteem when self-regulation was impaired by prior use.

Another basis for the hypothesis is that self-regulating increases confirmatory information processing [24]. After having self-regulated, people with high self-esteem may increasingly seek out information that confirms their self-perceived greatness, whereas people with low self-esteem may seek out information that confirms their negative self-views.

A competing hypothesis, however, is that self-regulation is used to maintain positive illusions [25]. One therefore might expect self-regulation to be influential among people with low self-esteem—who might use selfregulation to maintain positive views_-but not among people with high self-esteem.

Participants first completed a task that either did or did not require self-regulation and then interacted with another participant. After the interaction, they indicated the extent to which they viewed positively their interaction partner and to which they perceived their partner as having viewed them positively. We predicted that participants with high self-esteem would overestimate how positively they were viewed, whereas participants with low self-esteem would underestimate how positively they were viewed, but that this relationship would be stronger among participants who had (v. had not) self-regulated.

\section{Method}

Thirty-two (20 women, 12 men) college undergraduates participated in fulfillment of a course requirement. Participants completed a measure of self-esteem [26] during a mass testing session at the start of the semester. The Rosenberg Self-Esteem Scale contains 10 items (e.g., "On the whole, I am satisfied with myself”) answered on a scale from 1 (strongly disagree) to 5 (strongly agree). Higher scores on this measure indicate higher self-esteem.

Participants attended a laboratory session later in the semester. They first completed a task that either did or did not require self-regulation. Specifically, participants watched a 6-minute video of a woman talking (without sound) in which neutral words appeared in the corner of the screen. Participants and interaction partners randomly assigned to the attention control condition were asked to avoid looking at the words and to focus their attention on the woman's face. Attention orients automatically to novel stimuli appearing in the environment [27], 
and so the task required the self-regulation of attention to avoid looking at the words. Participants and interaction partners randomly assigned to the watch normally condition were asked to watch the video as they would normally, which required little or no self-regulation. After the video ended, participants completed the Brief Mood Introspection Scale (BMIS) [28]. The BMIS contains 20 items indicative of mood (e.g., happy, sad) and arousal (e.g., peppy, drowsy). Participants rated each item to indicate how they were feeling at the present moment, using a scale from 1 (definitely do not feel) to 7 (definitely feel).

After the video task, participants were introduced to their interaction partner (another participant). They were given five topics (i.e., academic majors, origins and family, stress, a happy memory, and self-change) to discuss during a 5-minute conversation with one another. After the conversation, participants completed (in individual rooms) a questionnaire in which they evaluated themselves and their partner on various dimensions. The questionnaire asked participants to rate themselves and their interaction partner on the extent to which they were self-centered, arrogant, friendly, nice, polite, judgmental, and unfriendly during the interaction, using a scale from 0 (not at all) to 10 (extremely).

\section{Results}

\subsection{Positivity}

We created a measure of positively biased self-evaluation by creating composite measures of ratings (i.e., selfratings of friendly, nice, and polite, and-reverse scored — self-centered, arrogant, judgmental, and unfriendly) for the extent to which participants viewed themselves positively $(\alpha=0.82)$ and to which they were viewed positively by their interaction partner $(\alpha=0.87)$. The difference between these two composites (i.e., self-positivity - partner-positivity) indicated one's positivity bias, with larger scores indicating larger overestimations of the extent to which one was viewed positively.

Self-esteem scores correlated with the extent of positivity bias, $r(32)=0.39, p<0.05$. Higher self-esteem was associated with overestimating the extent to which the self was rated positively, whereas lower self-esteem was associated with underestimating the extent to which the self was rated positively. This finding is consistent with past work showing biases in self-perception based on self-esteem [7]-[9].

To examine whether the positivity bias differed as a function of self-esteem, we conducted a regression analysis that predicted positivity bias from self-esteem scores, video condition (attention control v. watch normally), sex, and all higher-order interactions. Sex was included because self-esteem scores were found to differ by sex in one condition. The analyses indicated a significant interaction between self-esteem scores and video condition, $\beta=4.18, t=2.15, p<0.05$. Correlational analyses (controlling for sex) indicated that the relationship between positivity bias and self-esteem scores was significant in the attention control condition, $r(11)=0.86, p$ $<0.001$, but not in the watch normally condition, $p>0.21$. The correlations in the two conditions were significantly different from each other, $z=-2.11, p<0.05$. Thus, the positivity bias was stronger among participants who had previously self-regulated.

\subsection{Mood Valence and Arousal}

Mood valence and arousal did not differ by video condition, $F \mathrm{~s}<0.20, p s>0.65$. Moreover, the relationship between positivity bias and self-esteem scores was significant in the attention control condition even when also controlling for mood valence and arousal, $r(9)=0.84, p<0.001$, but not in the watch normally condition, $p>$ 0.15 . This suggests that the obtained results were not attributable to the video task having influenced mood or arousal.

\section{Discussion}

The current study found that self-esteem predicted biases in estimating the extent to which others viewed oneself positively, but that this relationship was strongest among participants who had previously self-regulated. High self-esteem was associated with overestimating the extent to which another person ascribed positive traits to the person, whereas low self-esteem was associated with underestimating ascribed positivity, yet this tendency was stronger after participants had self-regulated. These findings suggest that self-regulation is used to maintain moderate views about the self. When self-regulation is impaired by prior use, biases emerge, as people return to their dominant, habitual modes of thought. People high in self-esteem might regulate their self-views to avoid 
being arrogant or narcissistic [15], whereas people low in self-esteem might regulate their views so as to avoid being unrealistically negative about the self (e.g., following societal standards to avoid derogating the self and view the self positively).

Some work indicates that self-regulation is used to maintain positive views [25]. Consistent with this work, people with low self-esteem had more negative self-views after having self-regulated. People with high self-esteem, however, exhibited increased positivity after having self-regulated. When energy is reduced, such as after having self-regulated [22], biases can emerge so that activities requiring energy seem more effortful [29]. Prior work examined mostly positive illusions regarding the capacity of the self (e.g., subjective control, perceptions of one's abilities), and likewise linked the energy-depleted state to perceptions of a weaker self. The current work differs because it examined perceptions of self-positivity.

Past work on the aftereffects of self-regulation has found that individual differences moderate the effects of self-regulation upon later self-regulation, when those differences are related to the domain of self-regulation [16]. Specifically, past work has shown moderation by eating restraint for eating consumption [30] [31], the motivation to respond without prejudice for stereotype suppression [32], the temptation to drink alcohol for alcohol consumption [33], sex drive for sexual restraint [34], and attachment style for interpersonal functioning [15]. The current work indicates that self-esteem moderates self-views following self-regulation.

The aftereffects of self-regulation appear attributable to decreases in blood glucose levels [20] [22]. This suggests that biases related to self-esteem might emerge more strongly after people have self-regulated because glucose is lower. It is therefore possible that low glucose might increase biases related to self-esteem. When glucose is low, people lack the metabolic energy needed to maintain moderate, socially appropriate self-views.

Many studies have linked low glucose or problems with glucose to an increased likelihood of depression [21]. There are strong links between depression and low self-esteem [35]. It is possible that people with depression view themselves negatively because of low glucose or problems with glucose, consistent with the current finding that self-regulating increases negative self-views among people with low self-esteem. This effect could worsen or prolong depressive symptoms.

The amount of metabolic energy that can be used during any given amount of time is limited [36]. Energy used by one process (e.g., reproduction) therefore can divert energy away from and impair other processes (e.g., self-control) [37]-[40]. If the current effects are indeed linked to low glucose, then metabolic demands that deplete glucose (e.g., the growth of cancer cells, immune defense, excessive physical exercise) could increase biases related to self-esteem. Maintaining moderate views requires glucose for self-regulation that cannot be diverted to other processes without impairment.

\section{References}

[1] Buhrmester, D., Furman, W., Wittenberg, M.T. and Reis, H.T. (1988) Five Domains of Interpersonal Competence in peer Relationships. Journal of Personality and Social Psychology, 55, 991-1008. http://dx.doi.org/10.1037/0022-3514.55.6.991

[2] Baumeister, R.F., Campbell, J.D., Krueger, J.I. and Vohs, K.D. (2003) Does High Selfesteem Cause Better Performance, Interpersonal Success, Happiness, or Healthier Lifestyles? Psychological Science in the Public Interest, 4, 1-44. http://dx.doi.org/10.1111/1529-1006.01431

[3] Harter, S. (1993) Causes and Consequences of Low Self-Esteem in Children and Adolescents. In: Baumeister, R., Ed., Self-Esteem: The Puzzle of Low Selfregard, Plenum Press, New York, 87-116. http://dx.doi.org/10.1007/978-1-4684-8956-9_5

[4] Diener, E., Wolsic, B. and Fujita, F. (1995) Physical Attractiveness and Subjective Wellbeing. Journal of Personality and Social Psychology, 69, 120-129. http://dx.doi.org/10.1037/0022-3514.69.1.120

[5] Gabriel, M.T., Critelli, J.W. and Ee, J.S. (1994) Narcissistic Illusions in Selfevaluations of Intelligence and Attractiveness. Journal of Personality, 62, 143-155. http://dx.doi.org/10.1111/j.1467-6494.1994.tb00798.x

[6] Miller, C.T. and Downey, K.T. (1999) A Meta-Analysis of Heavyweight and Selfesteem. Personality and Social Psychology Review, 3, 68-84. http://dx.doi.org/10.1207/s15327957pspr0301 4

[7] Battistich, V., Solomon, D. and Delucchi, K. (1993) Interaction Processes and Student Outcomes in Cooperative Learning Groups. The Elementary School Journal, 94, 19-32. http://dx.doi.org/10.1086/461748

[8] Frone, M.R. (2000) Interpersonal Conflict at Work and Psychological Outcomes: Testing a Model among Young Workers. Journal of Occupational Healthy Psychology, 5, 246-255. http://dx.doi.org/10.1037/1076-8998.5.2.246

[9] Glendinning, A. and Inglis, D. (1999) Smoking Behaviour in Youth: The Problem of Low Self-Esteem? Journal of 
Adolescence, 22, 673-682. http://dx.doi.org/10.1006/jado.1999.0262

[10] Bishop, J.A. and Inderbitzen, H.M. (1995) Peer Acceptance and Friendship: An Investigation of Their Relation to Self-Esteem. Journal of Early Adolescence, 15, 476-489. http://dx.doi.org/10.1177/0272431695015004005

[11] Heatherton, T.F. and Vohs, K.D. (2000) Interpersonal Evaluations Following Threats to Self: Role of Self-Esteem. Journal of Personality and Social Psychology, 78, 725-736. http://dx.doi.org/10.1037/0022-3514.78.4.725

[12] Adams, G.R., Ryan, B.A., Ketsetzis, M. and Keating, L. (2000) Rule Compliance and Peer Sociability: A Study of Family Process, School-Forced Parent-Child Interactions, and Children's Classroom Behavior. Journal of Family Psychology, 14, 237-250. http://dx.doi.org/10.1037/0893-3200.14.2.237

[13] Brockner, J. and Lloyd, K. (1986) Self-Esteem and Likability: Separating Fact from Fantasy. Journal of Research in Personality, 20, 496-508. http://dx.doi.org/10.1016/0092-6566(86)90128-5

[14] Campbell, J.D. and Fehr, B.A. (1990) Self-Esteem and Perceptions of Conveyed Impressions: Is Negative Affectivity Associated with Greater Realism? Journal of Personality and Social Psychology, 58, 122-133. http://dx.doi.org/10.1037/0022-3514.58.1.122

[15] Vohs, K.D., Baumeister, R.F. and Ciarocco, N.J. (2005) Self-Regulation and Self-Presentation: Regulatory Resource Depletion Impairs Impression Management and Effortful Self-Presentation Depletes Regulatory Resources. Journal of Personality and Social Psychology, 88, 632-657. http://dx.doi.org/10.1037/0022-3514.88.4.632

[16] Baumeister, R.F., Gailliot, M., DeWall, C.N. and Oaten, M. (2006) Self-Regulation and Personality: How Interventions Increase Regulatory Success, and How Depletion Moderates the Effects of Traits on Behavior. Journal of Personality, 74, 1773-1802. http://dx.doi.org/10.1111/j.1467-6494.2006.00428.x

[17] Baumeister, R.F., Vohs, K.D. and Tice, D.M. (2007) The Strength Model of Self-Control. Current Directions in Psychological Science, 16, 351-355. http://dx.doi.org/10.1111/j.1467-8721.2007.00534.x

[18] Gailliot, M.T. (2009) The Effortful and Energy-Demanding Nature of Prosocial Behavior. In: Mikulincer, M. and Shaver, P.R., Eds., Prosocial Motives, Feelings, and Behavior: The Better Angels of Our Nature, American Psychological Association, Washington DC.

[19] Muraven, M. and Baumeister, R.F. (2000) Self-Regulation and Depletion of Limited Resources: Does Self-Control Resemble a Muscle? Psychological Bulletin, 126, 247-259. http://dx.doi.org/10.1037/0033-2909.126.2.247

[20] Fairclough, S.H. and Houston, K. (2004) A Metabolic Measure of Mental Effort. Biological Psychology, 66, 177-190. http://dx.doi.org/10.1016/j.biopsycho.2003.10.001

[21] Gailliot, M.T. and Baumeister, R.F. (2007) The Physiology of Willpower: Linking Blood Glucose to Self-Control. Personality and Social Psychology Review, 11, 303-327. http://dx.doi.org/10.1177/1088868307303030

[22] Gailliot, M.T., Baumeister, R.F., DeWall, C.N., Maner, J.K., Plant, E.A., Tice, D.M., Brewer, L.E. and Schmeichel, B.J. (2007) Self-Control Relies on Glucose as a Limited Energy Source: Willpower Is More Than a Metaphor. Journal of Personality and Social Psychology, 92, 325-336. http://dx.doi.org/10.1037/0022-3514.92.2.325

[23] Vohs, K.D. (2004) The Health of Romantic Relationships Relies on Self Regulation. Society for Personality and Social Psychology, Austin.

[24] Fischer, P., Greitemeyer, T. and Frey, D. (2008) Self-Regulation and Selective Exposure: The Impact of Depleted Self-Regulation Resources on Confirmatory Information Processing. Journal of Personality and Social Psychology, 94, 382-395. http://dx.doi.org/10.1037/0022-3514.94.3.382

[25] Fischer, P., Greitemeyer, T. and Frey, D. (2007) Ego Depletion and Positive Illusions: Does the Construction of Positivity Require Regulatory Resources? Personality and Social Psychology Bulletin, 33, 1306-1321. http://dx.doi.org/10.1177/0146167207303025

[26] Rosenberg, M. (1965) Society and the Adolescent Self-Image. Princeton University Press, Princeton.

[27] Shiffrin, R.M. and Schneider, W. (1977) Controlled and Automatic Human Information Processing: II. Perceptual Learning, Automatic Attending and a General Theory. Psychological Review, 84, 127-190. http://dx.doi.org/10.1037/0033-295X.84.2.127

[28] Mayer, J.D. and Gaschke, Y.N. (1988) The Experience and Meta-Experience of Mood. Journal of Personality and Social Psychology, 55, 102-111. http://dx.doi.org/10.1037/0022-3514.55.1.102

[29] Proffitt, D.R. (2006) Distance Perception. Current Directions in Psychological Science, 15, 131-135. http://dx.doi.org/10.1111/j.0963-7214.2006.00422.x

[30] Kahan, D., Polivy, J. and Herman, C.P. (2003) Conformity and Dietary Disinhibition: A Test of the Ego-Strength Model of Self-Regulation. International Journal of Eating Disorders, 33, 165-171. http://dx.doi.org/10.1002/eat.10132

[31] Vohs, K.D. and Heatherton, T.F. (2000) Self-Regulatory Failure: A Resource-Depletion Approach. Psychological Science, 11, 249-254. http://dx.doi.org/10.1111/1467-9280.00250 
[32] Gailliot, M.T., Plant, E.A., Butz, D.A. and Baumeister, R.F. (2007) Increasing Self-Regulatory Strength Can Reduce the Depleting Effect of Suppressing Stereotypes. Personality and Social Psychology Bulletin, 33, 281-294. http://dx.doi.org/10.1177/0146167206296101

[33] Muraven, M., Collins, R.L. and Nienhaus, K. (2002) Self-Control and Alcohol Restraint: An Initial Application of the Self-Control Strength Model. Psychology of Addictive Behaviors, 16, 113-120. http://dx.doi.org/10.1037/0893-164X.16.2.113

[34] Gailliot, M.T. and Baumeister, R.F. (2007) Self-Regulation and Sexual Restraint: Dispositionally and Temporarily Poor Self-Regulatory Abilities Contribute to Failures at Restraining Sexual Behavior. Personality and Social Psychology Bulletin, 33, 173-186. http://dx.doi.org/10.1177/0146167206293472

[35] APA (American Psychiatric Association) (1994) Diagnostic and Statistical Manual of Mental Disorders. 4th Edition, (DSM-IV) American Psychiatric Association, Washington, DC, 715-718.

[36] Kleiber, M. (1961) The Fire of Life: An Introduction to Animal Energetics. Krieger, New York.

[37] Aiello, L.C. (1997) Brains and Guts in Human Evolution: The Expensive Tissue Hypothesis. Brazilian Journal of Genetics, 20, 141-148. http://dx.doi.org/10.1590/S0100-84551997000100023

[38] Aiello, L.C. and Wheeler, P. (1995) The Expensive-Tissue Hypothesis: The Brain and the Digestive System in Human and Primate Evolution. Current Anthropology, 36, 199-221. http://dx.doi.org/10.1086/204350

[39] Aiello, L.C., Bates, N. and Joffe, T.H. (2001) In Defense of the Expensive Tissue Hypothesis. In: Falk, D. and Gibson, K.R., Eds., Evolutionary Anatomy of the Primate Cerebral Cortex, Cambridge University Press, Cambridge, 57-78. http://dx.doi.org/10.1017/CBO9780511897085.006

[40] Gailliot, M.T., Hildebrandt, B., Eckel, L.A. and Baumeister, R.F. (2010) A Theory of Limited Metabolic Energy and Premenstrual Syndrome (PMS) Symptoms: Increased Metabolic Demands during the Luteal Phase Divert Metabolic Resources from and Impair Self-Control. Review of General Psychology, 14, 269-282. http://dx.doi.org/10.1037/a0018525 